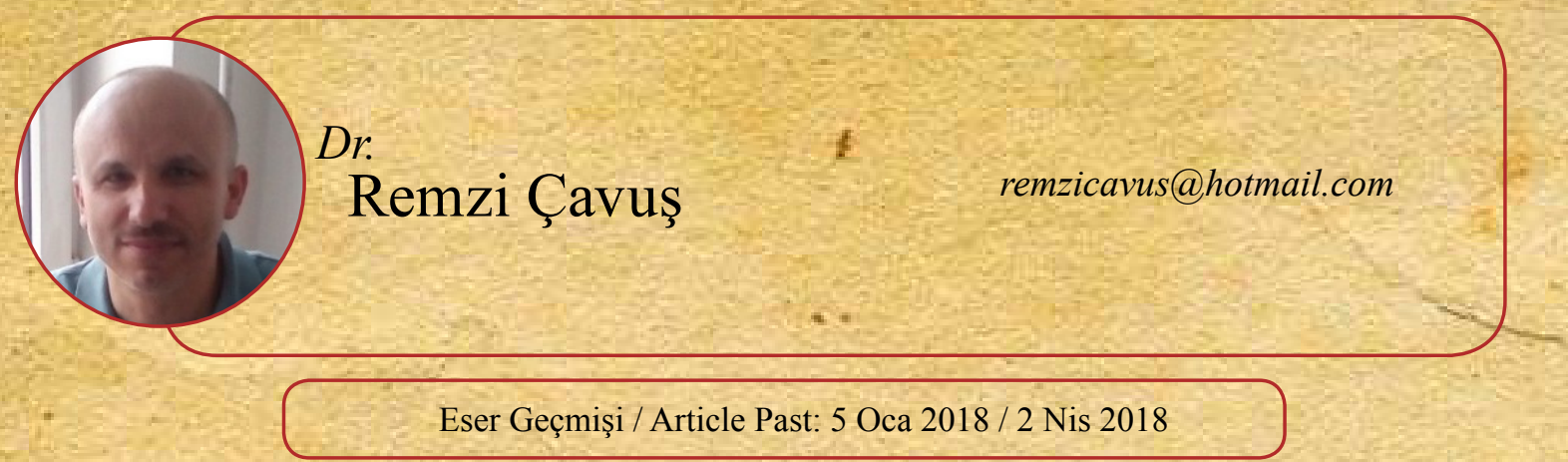

Araştırma Makalesi DOI: $10.21551 /$ jhf.375158 Research Paper Orjinal Makale / Orginal Paper

\title{
Geçmişin Yorumlanmasında Nüfus Defterlerinin Rolü
}

\author{
The Role of Population Books in Interpretation of History
}

\section{ÖZET}

Osmanlı Devleti'nde, modern anlamda, nüfus sayımları ilk defa II. Mahmut döneminde, 1829 yılında başlamış ve XX. yüzyılın başlarına kadar da devam etmiştir. Düzenli aralıklarla yapılmayan, askeri ve iktisadi amaçlar doğrultusunda olan bu sayımlar, genel itibariyle, Anadolu ve Rumeli' deki erkek vatandaşlarla sınırlı tutulmuştur. Yapılan nüfus sayımlarinı, nüfusla ilgili değişiklikleri ve açıklamaları içeren defterler, Nüfus Defterleri olarak adlandırılmıştır. Osmanlı Devleti'ndeki nüfusun nitelik ve niceliğini anlamada müracaat edilecek bir kaynak olan bu defterler, ülkedeki etnik ve dini yapıdan isim verme geleneğine kadar farklı konularla ilgili de bilgi sunmaktadır. Osmanlı alfabesiyle el yazısı halinde tutulan bu defterlerin önemli bir kısmı, günümüzde Başbakanlı Osmanlı Arşivi'nde, yönetim birimlerine göre tasnif edilmiş halde mevcuttur. Bu çalışmanın amacı nüfus defterlerinin fonksiyonunu ortaya koymaktır.

Anahtar Kelimeler: Osmanlı Devleti, Nüfus Defterleri, Nüfus Sayımı, Nüfus, Halk

\section{ABSTRACT}

In the Ottoman Empire, in the modern sense, for the first time in the population censuses. Began during the Mahmut II period, in 1829 and it continued until the beginning of the XX. century. Who performed at regular intervals, the secounts are in line with military and economic purposes, as a general, citizens in Anatolia and Rumelia was limited to men. Books containing the population censuses made, population changes and explanations are called Population Books. These books, which are a resource to be applied in the sense of the quality and quantity of the population in the Ottoman Empire, also provide information on various topics from the ethnic and religious structure of the country to the tradition of giving names. An important part of these books, hand written by the Ottoman alphabet, is presently 
classified in the Prime Minister's Ottoman Archives according to the administrative units. The aim of this study is to reveal the function of the population registers.

Keywords: Population Books, Ottoman, Population Census, Population, Folk

\section{Giriş}

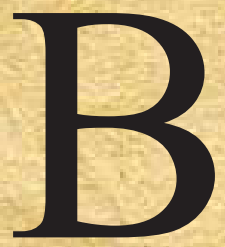

u çalışmada bir yerleşim yerinin nüfus özelliklerini ortaya koymak yerine "geçmişin yorumlanmasına nüfus defterlerinin nasıl bir katkısı olabilir?" sorusuna cevap vermeye çalıştık. Bunun için Drama, Samsun, Bursa, İstanbul, Amasya, Erzurum, Diyarbakır, Konya, Kastamonu, Sivas, Tokat, Antalya gibi yerleşim yerlerinin nüfus defterlerini inceledik. Farklı etnik ve dini toplulukları içeren defterleri bütünsel olarak anlayabilmek için Drama ve Canik'in merkez kazasına bağlı köy ve mahalleleri tek tek incelerken diğer yerleşim yerlerinin defterleri üzerinde kısmi çalışmalar yaptık.

Osmanlı Devleti'nde II. Mahmut dönemine kadar, modern anlamda, nüfus sayımı yapılmamıştır. 19. yüzyıldan önce Osmanlı Devleti mali imkânlarını tespit etmek amacıyla tımar sistemi içerisinde sayımlar yapmıştır. Tımar sistemi önemini kaybedince de avarız sayımları ön plana çıkmıştır. Tahrir ve avarız kayıtlarından hareketle 16 ve 17 . yüzyılda çok sayıda yerleşim bölgesinin tahmini nüfusu ortaya çıkartılmıştır. Bu kaynakların dışında vakanüvislerin, seyyahların ve elçilik görevlilerin yazdığı kitap veya raporlardan da araştırmacılar istifade etmiştir. 1826' da Yeniçeri Ocağının kaldırılması sonucunda yeni bir askerî yapılanmaya gidilmesi mecburiyetinin ortaya çıkması, ülkenin askerliğe elverişli erkek sayısının bilinmesi gerekliliğini ortaya çıkarmıştır. Bunun için 1828' de başlatılan nüfus sayımı Rusya'yla başlayan savaş sebebiyle 1829' da kesintiye uğramıştır. 1830 yılında başlayan sayım ise başarılı bir şekilde tamamlanmıştır. Bundan sonra 1838-1845, 1882 1893 ve 1905-1907 yıllarında genel nüfus sayımları yapılmıştır. Bunların haricinde, bazı yerleşim yerleriyle sınırlı kalan sayımlar da yapılmıştır. Sayımlar genel itibariyle Anadolu ve Rumeli’yi kapsamış; 1882 yılına kadar, sadece erkek nüfus sayılmıştır.'

Sayımın sağlıklı yapılabilmesi için halkın güven duyduğu kişiler (ulema, kadı, naib, müderris, hacegân vb.) sayım işlerinde görevlendirilmiştir. Sayım işinde muhtar, imam, kocabaşı ve kâhya gibi yerel yöneticilere de sorumluluklar yüklenmiştir. Bunlardan kendi idare sahasındaki giriş ve çıkışları, doğum ve ölümleri taşradaki defter nazırlarına bildirmeleri istenmiştir. Sayımlarda elde edilen neticelerin değerlendirilmesi ve yeniden işlenmesi için İstanbul' da Ceride Nezareti kurulmuştur. Görevlilere 1 ile 100 yaş arasındaki erkek nüfusu bizzat görerek kaydetmeleri, Müslüman, gayrimüslim, yerli ve yabanc1 ayrımına dikkat ederek tasnif yapmaları, kişileri isimleri, şöhretleri ve fiziksek özelliklerine

\footnotetext{
Ancak 1870-1880 yılları arasında Divriği’ de yapılan sayımda bayan nüfus da kayıt altına alınmıştır. Hasan Yüksel, “Osmanlı'da Modern Anlamda Yapılan İlk Nüfus Sayımına Göre Divriği’nin Demografi Yapısı”, Nüfus Bilim Dergisi, 2006-07, s. 73. Osmanlıda yapılan bazı nüfus sayımları ile alakalı ayrıntılı bilgi için bkz. Enver Ziya Karal, İlk Nüfus Sayımı 1831, DİE, Ankara, 1995, s. 8, 9, 10, 18; Mübahat S. Kütükoğlu, “1830 Nüfus Sayımına Göre Menteşe Sancağında Hane Nüfusu", Osmanl A Araştırmaları XXIII, İstanbul, 2003, s. 75, 76; Kemal H. Karpat, Ottoman Population 1830-1914, The University of Wisconsin Press, 1985, London, s. 6. Hava Selçuk, "Niğde'de Illk Nüfus Sayımı", The Journal of Academic Social Science Studies, V. 6, I.2, p. 1263-1294, 2013, s. 1267; Salih Akyel, Savaş Sertel, "Osmanlı Nüfus Defterlerinin Tarih Yazımındaki Yeri: 1840 Tarihli Çarsancak Kazası Gayrimüslim Nüfus Defteri Örneği", Journal of History and Future, c.1, S. 1, s. 95.
} 
göre vasıflandırmaları bildirilmiştir. Ayrıca kendilerinden 14 - 40 yaş grubundaki sağlıklı ve askerliğe elverişli olanların isminin üzerine mim harfi koyulması; gayrimüslim nüfusun ise ekonomik durumuna göre kaydedilmesi istenmiş̧ir. Buna bağl olarak da nüfus memuru, sayımını yapacağı yerleşim birimindeki erkek nüfusu tek tek huzuruna çağırarak yoklama yaparak kayıtları tutmuştur. ${ }^{2}$

Nüfus sayımıyla görevlendirilen memurlara yapacakları işle ilgili genel bir bilgilendirme yapıldığı halde 1830-1845 arasında yapılan sayımları ihtiva eden defterlerin benzer şekilde tutulmadığ 1 görülmektedir. Bir defterde kişilerin sakalının, kaşlarının ve burnunun şekline, gözlerinin rengine, boyunun kısalık ve uzunluğuna kadar değinilirken bir başka defterde kişilerin hiçbir fiziksel özelliği yazılmamıştır. Böyle bir durum sadece farklı sancakların defterlerine has değildir, Drama'da 1830 'da başlayan nüfus sayımını ihtiva eden defterlerde kişilerin fiziksel özellikleri verilmemişken 1838 'de başlayan nüfus sayımını ihtiva edenlerde ise fiziki özellikler orta boylu, kara sakallı tabiri kullanılmıştır. Bir defterde kişilerin doğum tarihleri yazılmışken bir başka defterde yazılmamıştır. Örneğin Canik Sancağı'nın merkez kazası olan Samsun'a bağlı köylerde ölüm ve doğum tarihleri verilmişken, Amasya Sancağı'na bağlı olan Lâdik'te 1831 yılı sayımında ölüm ve doğum tarihleri verilmemiştir. ${ }^{3}$ Diğer taraftan defterlerde genel itibariyle kişi kaydının altına ilgili kişinin yaşı verilmiştir. Mesela Sivas vilayetine bağlı Kazabâd'ta "sinn 50" şeklinde yazılmıştır. Fakat bazı defterlerde kişilerin yaşı verilmeyip doğum tarihi verildiği gibi kişilerin yaşının veya doğum tarihinin hiç yazılmadığı defterler de vardır. İnebolu ve Diyarbakır nüfus defterlerinde böyle bir durum söz konusudur. ${ }^{4}$ Defterlerin bir kısmında sayımı yapılan yerleşim yerinin toplam nüfusu, ilgili yerleşim yerinin sonuna yazılırken bazı defterlerde böyle bir uygulama yoktur. ${ }^{5}$ Ayrıca hane numaralarının verilmediği defterlerde kimin hangi haneye mensup olduğu konusunda belirsizlikler olduğu gibi geniş ailelerde çocukların kimin oğlu veya torunu olduğu konusunda da açıklık yoktur. Örneğin Samsun'a bağlı Kapaklı Köyü'nde "torunu Mustafa", "torunü Osman” gibi kayıtlar yapılmıștır. Fakat ilgili torunun, hane reisinin oğlundan $\mathrm{m}$ k kızından $\mathrm{m} ı$ veya hangi oğlundan veya hangi kızından olduğuna dair açıklık yoktur. ${ }^{6}$ Defterlerdeki bu farklılıklar, birden çok vilayet veya sancakla ilgili değerlendirmeler yapmak isteyen araştırmacılar ile şecere araştırması yapanların işini zorlaştırmaktadır.

İstanbul'la ilgili nüfus defterleri, taşrayla ilgili olanların çoğuna göre daha düzenli tutulmuştur. Medrese talebeleri, firıncılar, değirmenciler, han ve kapanlarda çalışan hamallar, iskelelerde kayıkçlık yapanlar, daha başka zanaat ve esnaf grupları için ayrı

2 BOA, HAT, 336/19258; BOA, HAT, 336/19258-B; BOA,HAT, 335/19217; Nedim İpek, Rıza Karagöz, Cihat Uslucan, Canik Sancağı Samsun Kazasının Nüfus Yapısı, Canik Belediyesi, Samsun, 2016, S. 1-3; Muammer Demirel, Bursa Nüfus Kütüğ̈̈ 1830, Bursa Büyükşehir Belediyesi Kitaplığı, Bursa, 2014, s. 11-13; Sezgin Demircioğlu, Süleyman Bilgin, Of Nüfus Defteri, Senyıldız, İstanbul, 2011, s. 2-4; Mahir Aydın, "Sultan II. Mahmud Döneminde Yapılan Nüfus Tahrirleri”, Sultan II. Mahmud ve Reformlart Semineri 28-30 Haziran 1989, İstanbul Üniversitesi Edebiyat Fakültesi Basımevi İstanbul, 1990, s. 84-86.

3 NFS.d.1020;NFS.d.2231/2,3;NFS.d.4564;NFS.d.660/7;NFS.d.3423/2;NFS.d.5617/9; NFS.d.4545;NFS.d.4549; NFS.d.4550; Selim Özcan, "H. 1256 Tarihli Amasya Nüfus Defteri İle H. 1260-1261 Tarihli Amasya Temettuat Defterlerinin Karşılaştırmalı Değerlendirilmesi”, Studies Of Ottoman Domain, c.6, S. 11, 2016, s. 100.

4 NFS.d.3833; NFS.d.3195/11; NFS.d.7064/4; NFS.d.3822/2; NFS.d.2613/31; NFS.d.2615/1.

5 NFS.d.981/69; NFS.d.3195/11; NFS.d.4550/3; NFS.d.2613/31; NFS.d.2732/2.

6 NFS.d.1020/22. 
defterler tutulmuştur. Kişiler boyuna, bıyığına, sakalına, ten rengine, yaşına ve babasına göre vasıflandırılmıştır. Birçok yerde kişilerin göz rengine ve burun şekline değinilmediği halde İstanbul'daki nüfus defterlerinde kişilerin göz rengi, burun ve kaş tipi "Ela gözlü, șivri burunlu, çatık kaşlı" gibi ifadelerle belirtilmiş; âdeta kişiler resmedilmiştir. İstanbul, dışarıdan göç alan bir şehir olduğundan hangi talebenin veya meslek erbabının nereden geldiğine de "Ayvacıklı Hüseyin", "Karahisarî Mehmet" şeklinde değinilmiştir. Ayrıca İstanbul'da bazı meslek erbabı ve halk grupları han ve bekâr odası gibi mekânlarda yatıp kalktığından bu tür meskenlerle ilgili olarak da defterler tutulmuştur. ${ }^{7}$ Bursa nüfusuyla ilgili defterler de birçok ile göre daha düzenli tutulmuştur. Kişiler İstanbul nüfusunu gösteren defterlerde olduğu gibi fiziki özellikleri, mesleği ve yaşıyla verilmiştir. ${ }^{8}$

İstanbul ve Bursa gibi büyük şehirlerde medrese talebeleri, firıncılar, değirmenciler ve daha başka gruplar ve kurumlar için ayrı defterler hazırlanması Osmanlı Devleti'nin sosyal yapısı üzerine araştırma yapanların işini kolaylaştırmaktadır. Mesela yoklamanın yapıldığ 1 tarihte İstanbul'daki medrese sayısı, hangi medreselerin nerelerde olduğu, hangi medresede kaç talebenin bulunduğu nüfus defterlerinden öğrenilebilmektedir. ${ }^{9}$

II. Mahmut döneminde, Yeniçeri Ocağı kaldırıldıktan sonra nüfus sayımına girişilmesinin başlıca amacı ülkedeki asker potansiyelini öğrenmek ve asker alımlarını elde edilen veriler doğrultusunda yapmaktır. Buna bağlı olarak da erkek nüfusun sayımı yapılmış; defterlere kişilerin yaşı, fiziksel özellikleri, sağlık durumları ve askerliğe uygun olup olmadığı yazılmıştır. ${ }^{10}$ Belirgin rahatsızlığı olan kişilerin isminin üzerine, a'mâ, meczup, divane, dilsiz, alîl (hasta), topal, çolak, bîzebân (dilsiz) gibi kayıtlar düşülmüştür. ${ }^{11}$ Defterlerin bazılarında, askerliğe uygun olanların üzerine "mim" harfi yazılmıștır. Kaç kissinin askerliğe uygun olduğu ise yerleşim yerinin bulunduğu bölümün sonuna "Matlub-1 Âliye Muvafik" başlığı altında verilmiştir.12 "Mim" harfi ise "Matlub-1 Âliye Muvafik" klişesinin kısaltması olarak kullanılmıştır. ${ }^{13}$ Ayrıca kişilerin ordudaki hangi birimde olduğu ise topçu, bahriye, mansure, redif, süvari şeklinde yazılmıştır. ${ }^{14}$ Kıptîlerle ilgili defterlerde ise kişilerin askerliğe uygun olup olmadığına dair kayıtlar yoktur. ${ }^{15}$ Defterlere kişilerin bu şekilde vasıflandırılarak kaydedilmesi, hâl-i hazırda ve gelecekteki asker potansiyelini görmek açısından faydalı olmuştur.

7 NFS.d.59/3; NFS.d.96/2; NFS.d.106/2,75; NFS.d.178/2,75; NFS.d.213/2,75; NFS.d.7075/7,8. Taşradaki yerleşimlerin bir kısmında medrese talebeleri için ayrı defter tutulsa da bazılarında ayrı defter tutmak yerine defterlerde, medreselerde okuyan kişilerin kaydının üzerine ve altına "talebe" ibaresi yazılmıştır. NFS.d.3230/4; NFS.d.3195/18.

8 NFS.d.1391/2,3; NFS.d.3833/3

9 Mehmet Güneş, “Osmanlı Dönemi Nüfus Sayımları ve Bu Sayımları İçeren Kayıtların Tahlili”, Akademik Bakış, c. 8, S. 15,2014 , s. $221-240$.

10 NFS.d.4549; NFS.d.4550; NFS.d.3195.

11 NFS.d.981; NFS.d.1011; NFS.d.1020; NFS.d.3215/3,4,6,9; NFS.d.7075/7,8.

12 NFS.d.3195/11, 18

13 Mahir Aydın, "Sultan II. Mahmud Döneminde Yapılan Nüfus Tahrirleri”, Sultan II. Mahmud ve Reformları Semineri 28-30 Haziran 1989, İstanbul Üniversitesi Edebiyat Fakültesi Basımevi İstanbul, 1990, s. 83, 87; Selim Özcan, "H. 1256 Tarihli Amasya Nüfus Defteri İle H. 1260-1261 Tarihli Amasya Temettuat Defterlerinin Karşılaştırmalı Değerlendirilmesi”, Studies Of Ottoman Domain, c.6, S. 11, 2016, s. 100.

14 Y.EE, 42/163; Y.PRK.UM, 2/25, 5 L 1297; NFS.d.1020; NFS.d.1021; NFS.d.1023; NFS.d.3215/3,4,6,9; NFS.d.2231/2,3; NFS.d.7075/7,8. 
Askerî ve mali amaçlar doğrultusunda yapılan sayımlar sonucunda ülkedeki nüfus miktarı öğrenilmiştir. Bu, Nüfus Defterlerinin öncelikle sunduğu bir faydadır. Bunun yanı sıra defterlerden nüfusun yaş gruplarına göre dăğılımı da öğrenilebilmektedir. Sayımla vazifelendirilen görevlilerden bir kısmının, tutmuş olduğu defterin sonuna yaş gruplarıyla ilgili rapor yazmış olması araştırmacıların işini kolaylaştırmaktadır. Mesela Drama'nın Müslüman yerleşimleriyle ilgili olan 4545 numaralı defterin sonunda bir yaşından on beş yaşına kadar olanların sayısı 4.213, on beş yaşından kırk yaşına kadar olanların sayısı 3.080 ve kırk bir yaşından doksan yaşına kadar olanların sayısı 1.325, toplam nüfus ise 8.618 kişi olarak verilmiştir. ${ }^{16}$ Fakat günümüzdeki araştırmacılara kolaylık sağlamış olan böyle bir uygulama tüm defterlerde mevcut değildir.

Sayımın Rumeli ve Anadolu'yu kapsadığı, bayan nüfusunun sayılmadığı, bazı defterlerin kaybolduğu, yandığ 1 veya deforme olduğu bilinmektedir. ${ }^{17}$ Bunun dişında halkın, değişik yükümlülükler altına gireceğini düşünerek sayım memurlarına doğru bilgi sunmamış olmaları ihtimali de oldukça yüksektir. Dolayısıyla Nüfus Defterleri, Osmanlı ülkesindeki nüfus yapısını öğrenmek için tek başına yeterli bir kaynak değildir.

XIX. yüzyıldaki nüfus sayımları, yıllarca uygulanmış olan millet sistemine göre yapılımıştır. Müslümanlar, gayrimüslimler ve Çingeneler için ayrı defterler tutulmuştur. Elde edilen verilerden yola çıkılarak hazırlanan istatistiklerde ise gayrimüslimler Rum, Bulgar, Yahudi, Ulah olmak üzere kendi içlerinde tekrar bir sınıflandırmaya tabi tutulmuştur. Böylece sayımı yapılmış yerleşim yerlerindeki etnik yapı hakkında da bilgi sunulmuştur. ${ }^{18}$

Nüfus Defterlerinde kişilerin mesleklerinin kaydedilmiş olması, ülke içinde, mesleklerin dağılımı konusunda bilgi edinilmesine imkân sağlamaktadır. Özellikle İstanbul ve Bursa gibi büyük şehirlerde meslek grupları için ayrı defterler tutulması, araştırmacıların işini kolaylaştırmaktadır. Kırsal kesimlerle ilgili defterlerin bir kısmında, hane reislerinin her biri için "rençper" kaydı düşülürken bazı defterlerde, köy halkının meslek durumuna yer verilmemiştir. Şehir merkezlerinde yaşayanların meslek durumları ise belirtilmiştir. Mesela Samsun köylerinde kişilerin hayvancılıkla veya tarımla ilgilendiğine değinilmezken, merkez mahallelerinden birisi olan Kadıköy'de kimin hangi mesleği yaptığı Daşçı Hırşa, Așçı Kostanti, Dülger Dimitri, Marangoz Yani şeklinde yazılmıştır. ${ }^{19}$ Defterlerden hangi mesleklerin hangi halk grubu tarafından yapıldığı da anlaşılabilmektedir. Örneğin 4564 numaralı defter incelendiğinde Kıptîlerin (Çingeneler) sepetçilik, kalaycılık ve demircilik gibi mesleklerde yoğunlaştığ 1 görülmektedir. ${ }^{20}$ Nüfus Defterlerinde kişilerin mesleklerinin belirtilmesi, cephe gerisindeki ordu birimlerine yönelik asker alımlarının isabetli yapılmasını kolaylaştırdığı söylenebilir.

Ülke içindeki yatay hareketlilik ve dışarıdan olan göçler hakkında bilgiler içermesi, Nüfus Defterlerinin sunduğu bir başka faydadır. Ülke sınırları dışında kalmış yerlerden

16NFS.d.4545/24.

17NFS.d.2737/2.

18 NFS.d.5617/9; NFS.d.660/7; NFS.d.3423/2; NFS.d.4564; NFS.d.981; NFS.d.1011; NFS.d.1021; NFS.d.4550; NFS.d.4554; NFS.d.7450/21.

19NFS.d.4550; NFS.d.1023; NFS.d.981/69.

20 NFS.d.4564; NFS.d.5617/9; NFS.d.660/7; NFS.d.3423/2. 
gelerek yerleştirilmiş olanlar için ayrı defterler tutulmuştur. Ülke içinde yaşanan yer değişimleri ise defterlerde, göç eden kişinin isminin altına veya üstüne nerden geldiğine ( $b u$ günlerde Adana tarafindan geldiler) veya nereye gittiğine (vatan-l asliyesine gitmiştir) dair açıklamalar yazılarak belirtilmiştir. ${ }^{21}$ Bunun yanında Trabzonlu Nikola, Giresunlu Mihail, Tokatlığlu Todor; Sinoplu Lefter, Kürtoğlu, Cezayirli şeklinde kişi lakapların yazılması da ülke içindeki yatay hareketlilik konusunda bilgiler vermektedir. ${ }^{22}$

Bir sancağın sayımıyla görevlendirilen memur, sayım işini sancak merkezinden başlatarak kırsala doğru yaymış ve tutmuş olduğu defterde köylerle şehir merkezinin mahallelerini ayrı bir şekilde tutmuştur. Nüfus Defterlerinde şehir merkezlerinde ve kırsal sahada meskûn halk tasnif edilmiş bir şekilde yerini -almıştır. Dolayısıyla bu defterler, şehirlerle kırsal sahanın nüfusu üzerinde yapılacak mukayeselere de zemin oluşturmaktadır.

Nüfus Defterleri, isim koyma geleneği üzerine araştırma yapanların müracaat edebileceği bir kaynak çeşididir. Türk-İslam nüfusunun yazıldığı defterlerde Muhammed, Ömer, Bekir, Hasan gibi İslam büyüklerinin isimlerine sık bir şekilde rastlanmasının yanında aile büyüklerinin isimlerinin yeni doğan çocuklara verilmesinin yaygın bir gelenek olduğu görülmektedir. Örneğin Mustafa'nın torununa Mustafa ismi verilmiștir. Böyle bir geleneğin gayrimüslimlerde de yaygın olduğu anlaşılmaktadır. Mesela Yani'nin torunun adı Yani, Lefter' in torununun adı Lefter, Hazar'ın torununun adı Hazar'dır. ${ }^{23}$ Defterlerde görülen ilginç bir ayrıntı ise babayla oğlun Hasan Oğlu Hasan, Mehmet Oğlu Mehmet şeklinde aynı ismi taşımasıdır. Böyle bir uygulamanın temel sebebi ise ölen babanın ismini devam ettirme düşüncesidir. Genellikle de babası öldükten sonra doğan veya babası öldüğünde daha birkaç aylık olan çocuklara baba ismi verilmiştir.

Nüfus Defterlerinden, sayımların yapıldığı dönemdeki meskûn mahalle ve köylerin isimleri öğrenilmektedir. Böyle bir durum yerleşim yerleriyle ilgili araştırmaları kolaylaştırmaktadır. Mesela Drama Sancağı Yunanistan'ın yönetimine geçtikten sonra buradaki köylerin isimleri değiştirilmiştir. Bük'ün adı Paranesti, Karaca'nınki Tholos, Karagöz'ünki ise Perivlepto yapılmıştır. Ayrıca, Osmanlı döneminde meskûn birer yerleşim olan bazı köyler ise yerleşim yeri olmaktan çıkmıştır.

Defterlerde görülen önemli ayrıntılardan birisi, gayrimüslimlerin isimlerinin kendi kültürlerini yansıtan Simon, Yani, Lefter, Yorgi gibi isimler olsa da lakapların Topaloğlu, Köroğlanoğlu, Tavşanoğlu, Delioğlanoğlu, İpekoğlu, Demiroğlu, Kürkçüoğlu gibi Türkçe olmasidir. $^{24}$

Gayrimüslimlerin kendilerine "gâvur" denmesinden hoşlanmadıkları ve Tanzimat Döneminde ilgili söylemin kullanılmasının yasaklandığı birgerçektir. Fakat gayrimüslimlerle ilgili Nüfus Defterlerinde "gâvur" kelimesinin bizzat Rumlar tarafından lakap olarak kullanıldığı görülmektedir. Mesela Samsun'a bağlı bir Rum köyü olan Çardakgerişi’nde

21 NFS.d.2231/2,3.

22 NFS.d.981/69; NFS.d.1011; NFS.d.59/3; NFS.d.96/2; NFS.d.106/2,75; NFS.d.178/2,75; NFS.d.213/2,75; NFS.d.3230/4.

23 NFS.d.2737/2; NFS.d.974; NFS.d.981; NFS.d.4550/10; NFS.d.2615/1.

24 NFS.d.2737/2; NFS.d.981; NFS.d.1011; NFS.d.7064/4; NFS.d.3833/3; NFS.d.7075/7,8. 
Karagâvuroğlu Sova ve Kara Gâvur Lazar isimleri; Rum yerleşimi olan Demirci Köyü’nde ise Karagâvuroğlu Papas ve Karagâvuroğlu Todor isimleri vardır. Bu köylerin tamamı Rum'dur ve dolayısıyla da ilgili lakapların kendileri tarafından konulmuş olma ihtimali oldukça yüksektir. ${ }^{25}$

Defterlerden aile yapılarıyla ilgili ayrıntılar elde edilebilmektedir. Yerleşim yerlerinde kaç ailenin küçük aile veya kaç ailenin geniş aile olduğu tespit edilmektedir. Bazı haneler baba ve annenin yanında dede, nine, amca ve halanın da yaşadığı kalabalık meskenlerdir. Mesela Samsun'a bağlı Kapaklı Köyü'nde 60 ve 40 yaşlarında iki kardeş olan Çavuşoğlu Hüseyin ve Mustafa aynı evde yaşamaktadır ve iki kardeşten her birinin üçer dörder tane erkek çocuğu görünmektedir. Bu kardeşlerin kız çocuklarının olabileceği ihtimali de vardır. Dolayısıyla da aynı evde yaşayanların sayısı 10 kişi civarındadır. ${ }^{26}$

Soyadın kullanılmadığı dönemlerde kişilerin lakaplarıyla tanındığı bir gerçektir. Böylece kimin hangi sülaleden geldiği de anlaşılabilmektedir. Fakat defterlerin tümünde kişi lakaplarına yer verilmemiştir. Mesela Samsun'la ilgili defterlerde, Çavuşoğlu, Zantaoğlu, Tafranoğlu gibi lakaplar belirtilirken Drama'yla ilgili defterlerde lakaplara pek yer verilmemiştir. ${ }^{27}$

Gayrimüslimlerle ilgili defterlerde kimlerin cizye vermekle yükümlü olduğu ve ne kadar cizye verdiğiyle ilgili bilgiler görülmektedir. Cizye vergisini yüksek derecede ödeyen isimlerin üzerine "a' lâ" kelimesinin kısaltması olan "ayın" harfi, orta derecede ödeyenlerin isimlerinin üzerine "evsat" kelimesinin kısaltması olan "tı" harfi ve düşük derecede ödeyen isimlerin üzerine "edna" kelimesinin kısaltması olan "nun" harfi konulmuştur. Edna, evsat ve a' ala kelimeleri, bazı defterlerde, kısaltma yapılmaksızın yazılmıştır. Birkaç yaşlarındaki çocuklar, belirgin rahatsızlığı olanlar ve yaşlıların yani cizyeden muaf olanların isimlerinin üzerine, cizye derecesini gösteren harfler yazılmamıştır. Yerleşim yerinin listesinin sonuna ise ilgili yerde a'la, evsat ve ednâ derecesinde kaç yükümlü olduğu; sagîr (küçük) ve amelmânde (iş yapamaz) durumunda kaçar kişinin bulunduğu yazılmıştır. ${ }^{28}$

Nüfus Defterlerinde hanelere ve kişilere numaralar verilmiștir. Böylece kimin hangi haneye mensup olduğu rahat bir şekilde anlaşılabilmektedir. Fakat tüm defterler bu şekilde tutulmamıştır. Mesela Konya, Erzurum ve Samsun'la ilgili defterlerde hane ve kişi sırasına ayrı ayrı yer verildiği halde Drama'yla ilgili nüfus defterlerinde hane belirtilmemiş sadece sıra numarası yazılmıştır. Diyarbakır nüfusunun kaydedildiği defterlerde hane numarası ve kişi numarasından hiç birisi yazılmamıştır. ${ }^{29}$

\footnotetext{
25 NFS.d.981; NFS.d.1011.
}

26NFS.d.974; NFS.d.1023/14.

27 NFS.d.1021/17,18; NFS.d.1023/14; NFS.d.4549; NFS.d.4550; NFS.d.7075/7,8. Kişilerin lakaplarıyla, mensubu olduğu sülalenin lakabıyla, mesleğiyle ve geldiği memleketle anılması Temettuat Defterlerinde de görülen bir uygulamadır. Mesela Dokak Bekir, Berber Mehmet, Kalaycı Hasan, Üsküdarlığlu Şerif, Bıyık Ali, Arnavut I Hasan, Erzurumlu Yusuf gibi. BOA, ML.VRD.TMT.d.13901.

28 NFS.d.7064/4; NFS.d.7065/2; NFS.d.3833/3; NFS.d.981/69; NFS.d.7075/7,8; NFS.d.3822/2; NFS.d.2737/2.

29 NFS.d.3215;NFS.d.2737; NFS.d.1020; NFS.d.1021; NFS.d.981; NFS. d.1011; NFS.d.4545; NFS.d.4549; NFS.d.4550; NFS.d.2615/1; NFS.d.2613/31 
Nüfus Defterlerinde genel itibariyle, köy veya mahallenin imam, rahip, muhtar ve çeribaşısının kim olduğu belirtilmiş, bunlar defterin ilk sıralarına yazılmıştır. ${ }^{30}$ Böylece, yoklamanın yapıldığı tarihte mahalle ve köylerin mülki ve dini işlerinden kimlerin sorumlu olduğunun tespit edilmesi, araştırmacılar açısından daha kolay hale gelmiştir. ${ }^{31}$

Osmanlı alfabesiyle yazılan Nüfus Defterlerinde, genel itibariyle, rik'a yazı tipi kullanılmıştır. Türkçe kelimeler yerine sıklıkla Arapça ve Farsça kökenli olan veled, bîzebân, yekçeşm, alîl, mücrim, amed, reft, fevt, amel-mânde, hânekeş, reaya, ilhak gibi kelimeler tercih edilmiştir. Ayrıca "Mehmet oğlu Hasan" şeklinde bir kullanım yerine Arap kültüründe olduğu gibi "Hasan İbni Mehmet", "İkinci Muhtar" biçiminde bir kullanım yerine "Muhtar-1 Sâni" şekli tercih edilmiştir. Nüfus defterlerinde bu şekilde bir dilin kullanılmasında, yıllarca sürmüş olan kültürel değişimin yanında tahrirlerin medrese mezunu kişilerce yapılmış olması da etkilidir.

Defterlerde kişiler boylarına göre "uzun", "orta" ve "kısa" olmak üzere vasıflandırılmıștır. Böyle bir sınıflandırma defterlerden toplumun boy durumuyla ilgili istatistiksel bilgilerin çıkarılabileceğini çağrıştırmaktadır. Fakat "uzun" ve "kısa" gibi vasıflandırmalarda hangi ölçütlerin temel alındığı belirtilmemiştir.

Defterlerin bazılarının baş kısmına, yoklaması yapılan köy ve mahallelerin fihristleri yazılmıştır. Böyle bir düzenleme defterlerden faydalanmayı kolaylaştırmıştır. Fakat defterlerin tümünde fihrist mevcut değildir.

İncelemiş olduğumuz nüfus defterleri 1830 ve 1845 yılları arasına aittir. 1922 yılında reșî varlığı sona eren Osmanlı Devleti, bu defterleri yüz yıla yakın muhafaza etmiștir. 1880 'den sonra daha teferruatlı ve sistemli sayımlar yapılıp defterler tutulduğu halde, pratik fayda açısından değeri düşen 1830-1845 arasındaki nüfus sayımlarını gösteren defterler imha edilmemiştir. Nüfus Defterlerine göre çok daha eski tarihlere ait olan binlerce resmî belgeyi ve nüfus defterlerini uzun bir süre muhafaza etmiş olması, Osmanlı Devleti'nin arşivciliğe yani devletin hafızasını korumaya verdiği önemi göstermektedir.

\section{Sonuç}

II. Mahmut döneminde başlamış olan nüfus sayımlarıyla ilgili tutulan defterler, maziyi daha iyi anlamak isteyen araştırmacılar için iyi bir kaynaktır. Bu defterlerden sadece ülkedeki nüfusun nicel durumuyla ilgili değil; dini ve etnik yapı, isim verme kültürü, mesleklerin dağılımı gibi farklı konularda da bilgi sahibi olunabilir. Fakat defterlerin halkın etnik, dini ve kültürel yapısını; ülkedeki nüfus miktarını öğrenmede tek başına yeterli bir kaynak olmadığı kabul edilmelidir.

Osmanlı Devleti'nin nüfus sayımlarına ait defterleri muhafaza etmiş olması, geçmişi anlamak açısından büyük bir önem arz etmektedir. Böylece nüfus miktarlarının yerleşim yerleri, yaş ve meslek grupları, etnik ve dini yapı açısından zamana göre değişim durumu farklı zaman aralıklarında yapılan nüfus sayımlarından takip edilebilmektedir.

30 NFS.d.3195/11; NFS.4550/2; NFS.d.1021/3; NFS.d.4564/2.

31 Muhtarlar ve dini temsilciler Vilayet Defterlerinden de tespit edilebilmektedir. 
Sayımla görevlendirilen memurlara yapacakları işle ilgili bilgilendirme yapılsa da nüfus defterlerinin tutulmasında benzer ölçülere uyulmamıştır. Bu durum defterlerden yapılacak bütünsel çıkarımların verimliliğini düşứrmektedir.

\section{Kaynakça}

Arşiv Belgeleri

BOA, HAT (Hatt-1 Hümayun)

$336 / 19258$

$336 / 19258-\mathrm{B}$

$335 / 19217$

BOA, ML.VRD.TMT.d (Maliye Varidatı Temettuat Defterleri)

13901

BOA, NFS.d (Nüfus Defterleri)

$59 ; 96 ; 106 ; 178 ; 213 ; 223 ; 660 ; 974 ; 981 ; 1011 ; 1020 ; 1021 ; 1023 ; 1391 ; 2231$; $2613 ; 2615 ; 2732 ; 2737 ; 3195 ; 3215 ; 3230 ; 3423 ; 3822 ; 3833 ; 4545 ; 4549 ; 4550 ; 4554$; $4564 ; 5617 ; 7064 ; 7065 ; 7075 ; 7450$

BOA, Y.EE (Yıldız Esas Evrakı)

$42 / 163$

BOA, Y.PRK.UM (Yıldız Perakende Umumi Evrakı)

$2 / 25$

\section{Kitap ve Makaleler}

Akyel, Salih, Sertel, Savaş, "Osmanlı Nüfus Defterlerinin Tarih Yazımındaki Yeri: 1840 Tarihli Çarsancak Kazası Gayrimüslim Nüfus Defteri Örneği”, Journal of History and Future, c. 1, S. 1, s. 78-98.

Aydın, Mahir, "Sultan II. Mahmud Döneminde Yapılan Nüfus Tahrirleri", Sultan II. Mahmud ve Reformlarl Semineri 28-30 Haziran 1989, İstanbul Üniversitesi Edebiyat Fakültesi Basımevi İstanbul, 1990, s. 81-106.

Demircioğlu, Sezgin, Bilgin, Süleyman, Of Nüfus Defteri, Şenyıldız, İstanbul, 2011. 
Demirel, Muammer, Bursa Nüfus Kütüğü 1830, Bursa Büyükşehir Belediyesi Kitaplığı, Bursa, 2014.

Güneș, Mehmet, "Osmanlı Dönemi Nüfus Sayımları ve Bu Sayımları İçeren Kayıtların Tahlili”, Akademik Baklş, c. 8, S. 15, 2014, s. 221-240.

İpek, Nedim, Karagöz, Rıza, Uslucan, Cihat, Canik Sancağı Samsun Kazasının Nüfus Yapısı, Canik Belediyesi, Samsun, 2016.

Karal, Enver Ziya, İlk Nüfus Sayımı 1831, DİE, Ankara, 1995.

Karpat, Kemal H, Ottoman Population 1830-1914, The University of Wisconsin Press, 1985, London.

Kütükoğlu, Mübahat S, "1830 Nüfus Sayımına Göre Menteşe Sancağında Hane Nüfusu", Osmanlı Araştırmaları, XXIII, İstanbul, 2003, s. 75-92.

Özcan, Selim, "H. 1256 Tarihli Amasya Nüfus Defteri İle H. 1260-1261 Tarihli Amasya Temettuat Defterlerinin Karşılaştırmalı Değerlendirilmesi”, Studies Of Ottoman Domain, c.6, S. 11, 2016, s. 97-118.

Selçuk, Hava, "Niğde'de İlk Nüfus Sayımı", The Journal of Academic Social Science Studies, V. 6, I.2, p. 1263-1294, 2013, s. 1263-1294.

Yüksel, Hasan, "Osmanlı' da Modern Anlamda Yapılan İlk Nüfus Sayımına Göre Divriği'nin Demografi Yapısı”, Nüfus Bilim Dergisi, 2006-07, s. 73-89. 


\section{Nüfus Defterlerinden Örnekler}

Örnek 1: Sivas Vilayeti, Kazabad Reaya Defteri

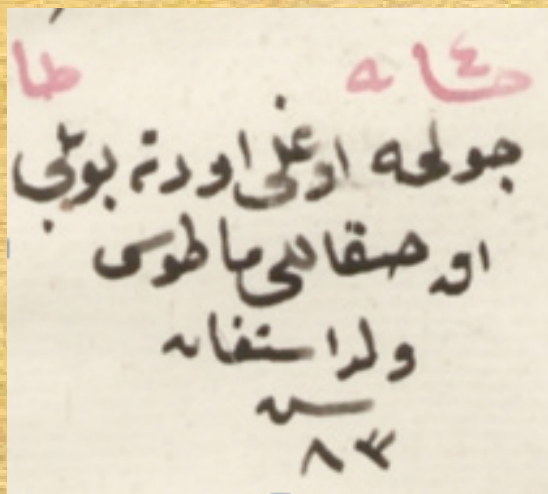

Hane 4

Evsat

Çulha Oğlu

Orta Boylu Ak Sakallı

MatosVeled istefan

Sinn 83

Örnek 2: Trabzon Vilayeti Canik Sancağı Bafra Reaya Defteri

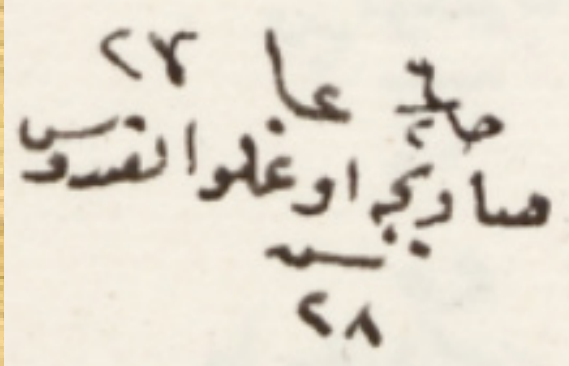

Hane 6

27

A'lâ

Sarıca Oğlu Anasdos

Sinn 28

Örnek 3: Sivas Vilayeti Amasya Sancağı Lâdik Müslim Defteri

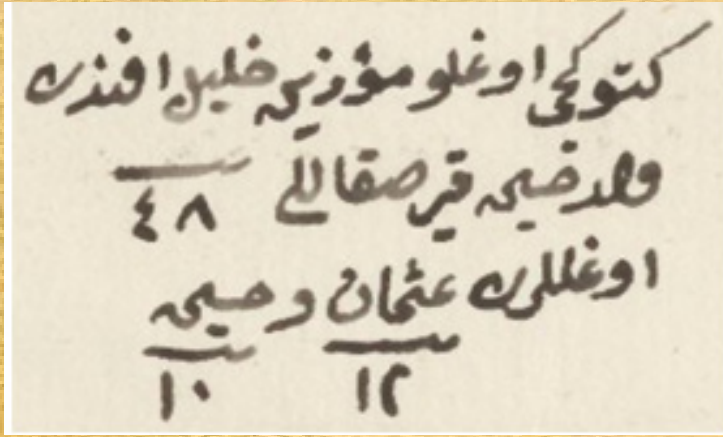

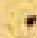

Kütükçü Oğlu

Müezzin Halil Efendi

Veled Hüseyin

Kır Sakallı

Sinn 48

Oğulları

Osman ve Hüseyin

Sinn 12, 10

Hüseyin Sinn 10 
Örnek 3: İstanbul, Medrese Talebeleri

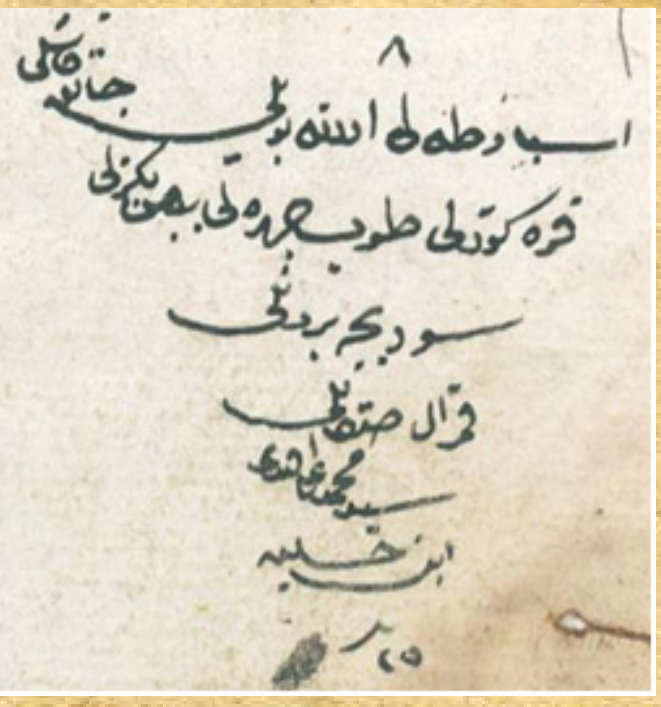

8

Ispartalı Orta Boylu

Çatık Kaşlı Kara

Gözlü

Top Çehreli Beyaz

Benizli

Sivrice Burunlu

Kumral Sakallı

Seyydi Mehmet Ali

Efendi Ibn Hüseyin

Sinn 25

Örnek 5: Erzurum Reaya Defteri

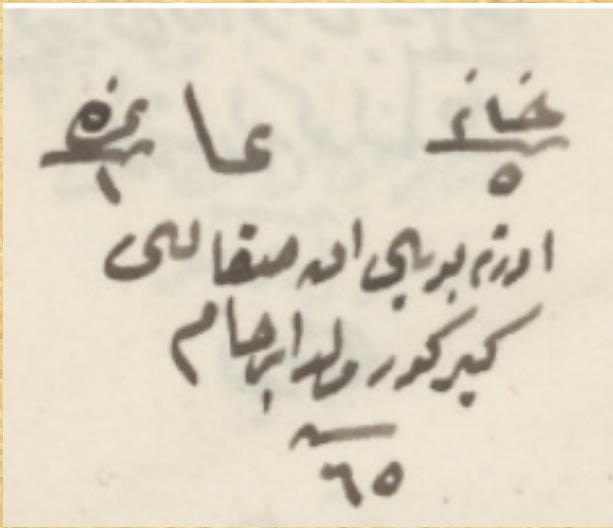

Hane 5

Numara 1

A'lâ

Orta Boylu Ak Sakallı

KirkorVeled

Abraham

Sinn 65

Örnek 6: Drama Sancağı Müslim Defteri

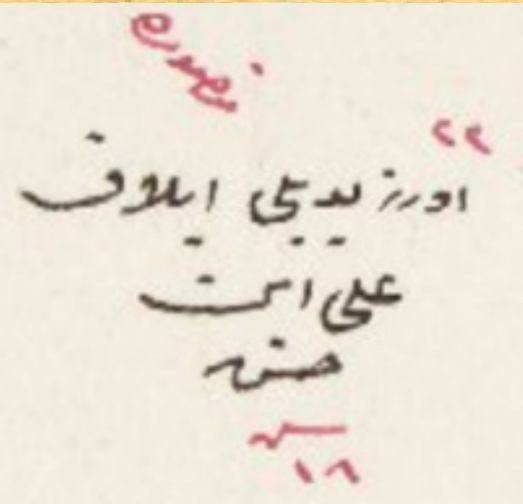

22

Mansure

Orta Boylu

Ablak

Ali Ibn Hasan

Sinn 18 